\title{
Use of Gender Based Vocabulary in Minangkabau Language
}

\author{
FY Susi ${ }^{1}$, Ermanto ${ }^{2}$ \\ \{ferasusi@student.unp.ac.id ${ }^{1}$, ermanto@fbs.unp.ac.id ${ }^{2}$ \} \\ ${ }^{1,2}$ Padang State University, 085278114245,082386298257, Indonesia
}

\begin{abstract}
The use of gender-based vocabulary in regional languages, especially Minangkabau language, is an interesting topic of study. This study aims to describe gender-based vocabulary in Minangkabau language. This research uses descriptive analysis method by using the referential equivalent method with the basic techniques, which select the determinant elements with advanced techniques, power to divide as a differentiator of referents. In this study, the authors found many uses of gender-based vocabulary in Minangkabau speech. There are four gender groups in the Minangkabau language, Masculine Gender, Feminime Gender, Common Gender and Neuther Gender. Feminine gender is a dominant vocabulary in Minangkabau language because it's more widely used than masculine gender. Vocabulary with female gender is more than male gender. The noun word class is found mostly in male and female gender but most of female gender is in adjectives class he noun word class is more than the class of adjectives both male and female gender.
\end{abstract}

Keywords: vocabulary, gender, expressiveness

\section{Introduction}

Male language is different from female language. The difference can be seen from the style of language, how to express, and the vocabulary spoken by male and female speakers. The difference in mastery of male and female languages is influenced by various aspects, namely aspects of education in the family, superiority and sociocultural [Yuliani, 2013] there is a mismatch of style of pronunciation, then the view is not common or unusual. The distinguishing aspects in commonly applied in the family environment and the level of superiority between gender and socio-cultural aspects. This creates a pattern of socialization that is applied to each gender and forms both gender styles of male and female language styles.

Language expressions describe the tendency of the speaker. In English it can be seen that there is a style of language that discriminates against women due to the factors of power and male dominance over women in various fields (Munjin, 2008) .Language expression reflects the speaker. Because the expression of this language appears the term asymmetry, unmarked terms, narrowing and giving meaning or negative meaning to words in English. 
Gender inequality in the Indonesian language is revealed in the naming of family status or marriage markers [Jaeni 2009]. Every married woman will follow the name of her husband or her husband's surname. This implies an inequality in gender. Women have limited roles, including in terms of language. In addition, according to Jaeni this gender difference in language can be found in Arabic. According to him, gender inequality in Arabic is more dominant than in Indonesian.

The representation of gender discourse in Indonesian and English phrases is discussed by [Budiwati, 2011]. The results of his research, based on intralinguistic analysis, Indonesian and English idioms and proverbs containing gender discourse in the form of nouns, noun phrases, verb phrases, adjective phrases, prepositional phrases, clauses, single sentences, single sentences / simple subjects omitted elliptical sentence), compound sentences equivalent, multilevel compound sentences, and mixed compound sentences. In addition, from the analysis of meanings and references, various meanings are known: one's weaknesses and strengths, successes, marriages, sexuality, negative things, and wisdom. Viewed from the culprit, the idiom and expression refer to male and female gender.

There are a lot of discussions about gender in foreign languages. For instance, comic "Chibimarukochan" discussed by [Nimas, 2013]. In the comic, the findings are male and female language differences seen from the use of personal pronouns, sentence end particles, interjections, nouns, and verbs. Women's language is more feminine while men's language is more masculine. Women's language is rarely used by men and vice versa. The danseigo male language is used by women when he is angry or talks with close friends and for the comic the author uses the children's language, ninsho, daimeishi, kandoushi and shuujoshi.

In French, the noun form in French is in the form of a gender marker (masculine-femina), the form of number markers (singular-plural), and the use of companion article nouns in French [Yuliati, 2016]. So, there is a formation process for masculine nouns and for feminine nouns. In Arabic, gender markers can not be separated from cultural elements because language is a mirror of the culture that surrounds it [Ardiansyah, 2017]. Gender markers in Arabic are dominated by bound morphemes and slightly free morphemes. In Arabic the division of gender or the separation of male and female gender is more stringent and also the complexity of language and its grammatical rules for male language and female language. Said Suhaidah investigated the lexical basis of gender in the Malay language in Malaysia to see an analysis of components of meaning. In this study women's lexicals are classified into family categories only and in Malay there is a form of gender, but not many [Said, 2005].

In Educational, male and female gender differences [Wekke, 2013]. Male boarding school education is different from female boarding school education. Male boarding schools develop vocabulary more in accordance with the field and environment. The differences also in teaching material, social factors, biology, learning environment and learning patterns. Whereas in teaching materials, there are differences in Arabic text of Mts students with scientific approaches [Shodiq 2016]. His findings include gender equality in textbooks. According to him, understanding the concept of gender ideology in students can be done in textbooks through gender perspective discourse. Illustrated images in textbooks are very influential on the level of student social development. Textbooks that reflect the quality of social relations between women and men are equal without any tendency to charge messages that are discriminatory and subordinate meaning. Then, indirectly will result in the acquisition of mental quality of students who will appreciate the spirit of gender equality. 
Minangkabau language is one of the many regional languages in Sumatra. The Minangkabau language is used by speakers of the Minang tribe in West Sumatra. In accordance with government regulations, local languages should be preserved. Then the enactment of Law No. 24 of 2009 articles 41 and 42 concerning the handling of regional languages and literature is the responsibility of the regional government and coordinates with the central government as a linguistic national policy maker. In accordance with the law, regional languages need to be preserved. The preservation of this regional language was done so that the regional language would not become extinct, so that the regional language would continue to be a repertoire of local culture and always be a characteristic of the area's people.

Based on the description above, it appears that gender differences in language are not only in everyday life, in comics, boarding schools and in textbooks. But the discussion about gender in local languages has not been pretty much covered. What is the gender vocabulary based on gender in the Minangkabau language? Authors interested in researching about it. This study aims to look at the use of gender-based vocabulary in the Minangkabau language and also to see the vocabulary productivity in speech. In line with this, the study also aims to describe the use of vocabulary based on gender in Minangkabau language.

\section{Research Methods}

This research includes qualitative research. The author uses descriptive analytical methods by using referential equivalent methods with basic techniques of technique, select the determinant elements with advanced techniques, power the breakdown as a differentiator. (Sudaryanto, 1993 ). This study discuss about vocabulary in Minangkabau sentences with the following procedure; first, collecting data by investigating the use of utterances or sentences in Minangkabau language, second, grouping data based on gender, third grouping based on word class, fourth analyzing data using referential methods with basic techniques of technique select determinants with advanced techniques with selective power as distinguishing referents and fifth presentation of the results of the analysis. The data analysis will also carried out by following the model of Miles and Huberman, namely data collection, reduction, presentation, and conclusions about the research findings and tringulation.

\section{Findings and Discussion}

Research on gender-based vocabulary will discuss all of the vocabulary in relation to gender in Minangkabau language. Vocabulary classified by gender and class determine the sentence or word in the speech. In this regard, the discussion about the language is considered central for two reasons: first, the language has a major contribution to the process of gender social construction and second language is related to the mechanisms of power that has implications on empowerment. Focus will be given to the study of sex and gender bias in the language, steriotipe and perceptions of language use both men and women, gender differences and similarities in linguistic and interactional in the use of language [Abdullah 2012]

In contrast to Arabic which distinguishes language into two gender groups namely men and women is muzakar and muanats. Then in Indonesian gender is divided into four groups. First Masculine Gender; namely nouns that have male sex. For instance, father, man, and uncle. Second, 
Feminine Gender which is a noun that has a female gender. For instance, mother, wife, and girl. Third Common Gender is a noun that can be male or female or of general sex. For instance teachers, parents, and employees. Fourth, Neuthers Gender are nouns that do not recognize gender, whether they are Masculine Gender or Feminine Gender. Rudi Haryono in [Ardiansyah, 2017] state the examples, There are books, gold, roads, money, pleasure and freedom

Language differences between men and women are looked in daily life (Kutjara, 2011). Vocabulary is describes more about women than men. This is causing women become the object of public attention than men. Selection of the vocabulary used by females to show the color also varies. According to Lakoff (in Kuntjara, 2011) men often underestimate the problem varied color nuances. For them, the difference was too small for the issue in the real world.

Vocabulary or lexicon is a language component that contains all the information about the meaning and usage of the word in the language; word wealth owned by a speaker, author or language; vocabulary; vocabulary; a list of words that are arranged like a dictionary but with a short explanation and practical (Kridalaksana, 1993). In connection with this study the authors used the term first language component that contains all the information about the meaning and usage of the word in the language.

Harimurti divides the class of words into thirteen namely verbs, adjectives, nouns, pronouns, numerals, adverbs, interogativa, demonstrativa, prepositions, conjunctions, phatic categories and interjections (Kridalaksana, 1994). The author will explain the results of vocabulary findings based on gender in the Minangkabau language and include any class of words the following words.

\subsection{Gender in Minangkabau Language}

There are four gender word groups in Minangkabau, namely masculine gender, feminine gender, gender and neuther commond gender.

\section{Masculine Gender}

Masculine gender is a noun that has a male gender. In the sentence or the Minangkabau language utterances there are found to be masculine gender. Sentences and utterances can be in the form of news sentences or statements, command sentences or question sentences. Examples of these sentences can be seen in the following sentence.

Kama abak tadi? (DN: 01)

'Where did father go?

Kalau pulang beko, jan lupo balian Sate Ajo. (DN:03)

'If you come home, don't forget to buy Ajo Satay"

Iyo sabana malang si Labai tu. Inyo tibo alek sudah.

(DN: 10)

How poor is Labai, he came after the party ended'

Pukua baru dijapuik marapulai tu? (DN: 18)

'What time does groom will be pick up?

Untuak acara bisuak, jan lupo cari pawang hujan.

(DN: 21) 
'For the event tomorrow, don't forget to look for a shaman'.

In the datum number (01) the word of abak includes masculine gender. The word $a b a k$ is a call for male parents in the Minangkabau community. In the datum number (03) the word of Ajo is a call for men in Pariaman, Ajo can not be replaced by other words and reserved exclusively for men only. In datum number (10) the word of Labai also included a call for men. Labai this means that a man who was called the prayer of salvation. In the datum number (18) the word meaning marapulai groom in Minangkabau also used only for men and for custom event wedding party. And the datum (21) said the handler, the handler says that means people who are experts in a particular field in a social community. Pawang is a profession that is usually only owned by men in Minangkabau communities such as rain handlers, snake charmers, and others.

The words abak, ajo, labai and handler include gender masculin which is a noun that has a male gender. Like father 'father', man 'male', and uncle 'uncle' in English [Ardiansyah, 2017].

\title{
Feminime Gender
}

Feminine gender is a noun that has a female gender. In the Minangkabau language also distinguishes sentences or utterances in the form of the female sex were found on the following words.

\author{
Anduangnyo maningga saminggu yang lalu. (DN: 41) \\ 'Her grandmother was died a week ago'. \\ Gadang bana sanggua mah, Piak? (DN: 59) \\ 'How big is is your bun, Piak?' \\ Lai bisa Leni jadi sumandan minggu katibo? (DN: 60) \\ 'Could Leni be bridesmaid next week?' \\ Baralek bisuak, carian lah suntiang nan agak baru. (DN: 61) \\ 'In the next wedding party, please find the newer suntiang. \\ Iyo sabana kamek inyo mamakai suntiang. (DN: 62) \\ 'She is very beautiful wearing a bride's headdress'
}

Based on the above examples there are several words containing female gender. In the datum number (41) Anduangnyo, this word means a woman's grandmother or a call to grandmother. In the datum number (59) The words of Piak is a call for girls in Minangkabau. In the datum number (60) The word of sumandan only for women because the meaning of sumandan is bridesmaids and this is usually in a traditional wedding ceremony. In the datum number (61) suntiang also includes the word containing female sex. The word of suntiang can't be used for men because this is the meaning suntiang headdress of the bride.

The words of anduang, sumandan, Piak include feminine gender; namely nouns that have female gender. As with the word mother 'mother' wife 'wife', and the lady 'girls in English [Ardiansyah, 2017]. While the word suntiang including culture, or culture with the word class of nouns, whereas adjectives kamek including class and gender can be used for women only. 


\section{Common Gender}

Common gender is a noun that can be male or female or of general sex. These words are general so they can be used for men and women. In Minangkabau we also find these types of words among them.

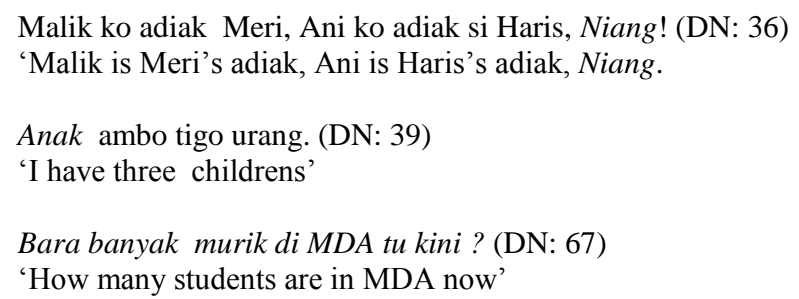

In the datum number (36) the word of adiak whose meaning brother and younger ones can be interpreted women and also men. Then in the datum number (39) My son is three. This sentence states the number of child speakers but the speaker does not say whether the child is male or female. In the datum number (67) too, the speaker asked the number of all students in the MDA but the speaker did not mention or ask which number of students were male students or the number of female students.

Then, word adiak, anak and murik are including common gender; namely nouns that can be male or female or of general sex. As an example of teacher, parent, and deer in English [Ardiansyah, 2017].

\section{Neuther Gender}

Also in Minangkabau language there are words that do not contain sex, it can be seen from the data below.

One pai manjanguak, sudah tu pai ka pasa lai. (DN: 54)

'My sister will make a visit condolence, after that she will go

to supermarket'

Kalau pai ka pasa, balian rendo yo! (57)

'If you go to the market, don't forget to buy lace!

Upiak pai ka lapau mambali sayua. (DN: 66)

'Upiak went to the departement store to buy vegetables'

Alah pulang, ayah Ang dari surau Yuang? (DN: 69)

'Has your father returned from the mosque, Yuang?

Minangkabau language have words that do not contain sex, it can be seen on the above account data. In the datum number (54) the word pasa neither for men nor women. Datum number 57 sayua also does not contain sex. Likewise, the word surau also does not contain sex. In 
conclusion, these words included neuther gender, as pasa, lapau, banang, panjaik sayua and surau these words do not have sex as in the word book, gold, street, money, happiness, pleasure, and freedom in English [Ardiansyah, 2017].

\subsection{Gender in the Nomina and Adjective Word Class in the Minangkabau Language}

Class words based on gender in Minangkabau are namely nouns and adjectives. The example can be seen in the following description.

\section{Nouns}

Nouns can be seen in terms of semantics and syntax. In terms of semantics, nouns are words that refer to humans, animals, objects and concepts of understanding. In terms of syntax, nouns tend to occupy subject, object or complementary functions Moeliono in [Yuliati, 2016]. Nouns can be found in the following data.

Buyuang pai mangaji ka surau dari tadi lai. (DN: 06)

'Buyuang went to recite the mosque.'

Jaan pai juo barubek ka dukun, ka rumah sakik se lah. (DN: 09)

'Don't go to a shaman, just go to the hospital! (DN: 14)

Kalau pai ka pasa, balian kupiah den yo, no 6. (DN: 14)

'When going to the market, buy a cap for me, it's the number 6.'

Den danga laki kau pai ka Jawa, iyo tu Piak? (DN: 16)

'I heard your husband went to Java, is that really, Piak?

Pukua bara dijapuik marapulai tu? (DN:18)

'What time does the groom get picked up?

The noun word class is very much found in male and female gender. On the record number (06) Buyuang words including nouns word classes with male gender. Data number (09) the word shaman also includes nouns with the male gender. So is the record number (14) word meaning kupiah cap also includes a noun with the male gender. (16) word meaning male husband is also included male gender and (18) word meaning marapulai also definitely include male gender. In addition, nouns are also present in female gender words, for example in the following data.

Bininyo urang Jawa. Dapek wakatu inyo kuliah di Jawa tu.

(DN: 43)

'His wife is Javanese. He knew while studying in Java.

Bundo pai ka pasa. Sabanta lai pulang tu mah. (DN: 45)

'Mother goes to the market, coming home soon.' 
Etek, jaikan baju ambo yo. Minggu katibo ka dipakai baralek.

(DN: 47)

Etek, sew my clothes on. Next week is used for a wedding party.'

Inyo kawin jo jando kayo. (DN: 48)

'He married a rich widow.

In the datum number (43) word bininyo which means the wife, the datum number (45) the word bundo which means mother (answering to the mother), the datum number (47) the word etek which means that the call for women younger than the mother or sister, mother, the datum number (48) the word jando which means widows (women who have no husband/divorced). All of the data includes nouns but for female gender.

\section{Adjective}

Language differences between men and women are looked in daily life (Kutjara, 2011). It is also in Minangkabau language that encountered gender adjectives containing either gender male and female. Adjectives with pretty much the female gender, but gender to male only slightly. Adjective word classes can be seen in the following data.

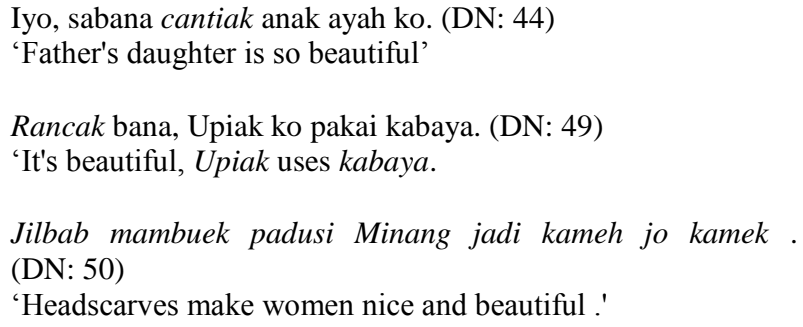

In the data number $(44,49,50,52,53$ and 48) the words cantiak, rancak, kamek, lantiak, and mantiak. All the words that included adjectives and used only for the female gender, where as datum number (48 and 28) coga, and tageh used only for the male gender. 
In the words cantiak, rancak, kamek, lantiak, and mantiak. All the words that included adjectives and used only for the female gender, while the word coga and tageh used only for the male gender. The adjective word class with its relation to gender is also influenced by Minangkabau culture or culture. As stated by Yuliani. Differences in the character of men and women who influenced the social culture that is associated with the presence status between the sexes both male and female, both the position and the role played gender [Yuliani, 2013]. In relation to language, gender also influence the vocabulary used in everyday conversation.

\section{Conclusions}

Gender in languages is not only found in Arabic, English, French, Japanese and Indonesian, but is also found in regional languages. In the Minangkabau language there are four gender groups namely masculine gender, feminine gender, common gender and neuther gender. Besides that, also found vocabulary with word class based on gender, namely noun and adjective class. But for language adjectives with female gender more than adjectives with male gender.

\section{Acknowledgments}

The author would like to thank Prof. Dr. Ermanto, S. Pd. M. Hum. who has guided in completing this article.

\section{Reference}

[1] Abdullah. I. Penelitian Berwawasan dalam Ilmu Sosial. Humaniora. Vol. 15. No. 3. pp. 265-275. (2012).

[2] Ardiansyah. Morfologi Gender dalam Bahasa Arab dan Inggris (Analisis Kontrastif dalam Fungsi Pengajaran Bahasa Arab.” At turats. Vol. 11. pp. 133-145 (2017).

[3] Budiwati. T. R. Representasi Wacana Gender Dalam Ungkapan Berbahasa Indonesia dan Bahasa Inggris: Analisis Wacana Kritis. Kawistara. Vol. 1. No. 3. pp. 133-145 ( 2011)

[4] Kridalaksana. H. Kelas Kata dalam Bahasa Indonesia. Indonesia. pp. 94-151. (1994)

[5] Kridalaksana. H. Kamus Linguistik. Indonesia. pp.127 (1993)

[6] Kutjara.E.Gender, Bahasa dan Kekuasaan. Indonesia. pp. 25-26 (2012)

[7] Munjin. Ekspresi Bahasa dan Gender Sebuah Kajian Linguistik. Yin Yang. Vo. 3 No. 2 pp. 262-274 (2008)

[8] Jaeni. M. Bahasa dan Ketimpangan Gender. Muwazah. Vol. 1 No. Bahasa dan Gender, pp. 165-172, (2009

[9] Said. S. Fital. S. N. J Che Pa.N.S Analisis Gender dalam Bahasa Melayu dari Sudut Leksikal dan Makna PB Antara Bangsa dspace. unimap. edu.my. (2014)

[10] Shodiq. M.J. Perspektif Kesetaraaan Gender dalam Buku Bahasa Arab Siswa MTs Pendekatan Saintifik

2013. Fenomena. Vol. 5 No. 1 (2013)

[11] Sudaryanto. Metode Penelitian Bahasa. Indonesia. pp. 13-23 (1993)

[12] Wekke. I. S. Gender_dalam_Materi_Belajar_Bahasa_Arab.pdf. Turast. Vol. 1 No. Gender dalam Materi Ajar ( 2013). 
[13] Yuliani. S. Perbedaan Gender dalam Penguasaan Bahasa dipandang dari Persfektif Psikologi Pendidikan Pedagogi. Vol. XIII. No. 1, pp. 47-51 ( 2013).

[14] Yuliati. R. Penanda Gender, Jumlah dan Artikel Pendamping Nomina Bahasa Prancis. Arbitrer Vo. 3 No. 1 pp. 71-77 (2016). 